\title{
The effect of acrylamide on human polymorphonuclear neutrophils in vitro
}

\author{
D. MANGAN AND I. S. SNYDER
}

From the Department of Microbiology, West Virginia University Medical Center, Morgantown, WV 26506, USA

ABSTRACT Acrylamide $\left(\mathrm{CH}_{2} \mathrm{CHCONH}_{2}\right)$, the vinyl monomer of the industrially useful polymer polyacrylamide, is a recognised neurotoxin. Investigation in our laboratory indicated that, in addition to its neurotoxic effect, acrylamide depressed human polymorphonuclear leucocyte (PMN) chemotaxis in vitro. As genetic or chemical inhibition of PMN phagocytic function frequently predisposes patients to repeated bacterial infections, the in vitro effects of acrylamide on several other human PMN functions were studied. Acrylamide in concentrations up to $37.5 \mathrm{mg} / \mathrm{ml}$ had no effect on trypan blue uptake. However, bacterial ingestion, killing, and induced chemiluminescence were depressed by pre-treatment with acrylamide $(10 \mathrm{mg} / \mathrm{ml})$. It seems unlikely that acrylamide exposure alters host resistance to bacterial infections, because (a) large doses of acrylamide are necessary to interfere with phagocytic functions, (b) acrylamide reacts readily with proteins on many tissue cells and may be made inaccessible or non-toxic to PMNs, and (c) PMNs have a rapid turnover rate in the body and non-functional cells would be rapidly replaced by functional cells.

The polymorphonuclear neutrophil leucocyte (PMN) is an important nonspecific defence against infection. Phagocytosis of bacteria, the main function of PMNs, can be divided into six functional steps: chemotaxis, opsonisation (recognition), ingestion, degranulation, activation, and bactericidal activity. Certain drugs, such as colchicine (Caner, 1965), steroids (Beisel and Rapoport, 1969), and ethanol (Brayton et al., 1970), temporarily depress one or more PMN phagocytic functions in vitro and are associated with increased host susceptibility to bacterial infections. Similarly, an inherited defect in a particular phagocytic function, such as in oxidative metabolism in chronic granulomatous patients (Holmes et al., 1967; Quie et al., 1967), or in chemoaxis in patients with the 'lazy leucocyte syndrome' (Miller et al., 1971), decreases the ability of the PMN to remove the bacterium effectively, and thereby predisposes the patient to infection.

Acrylamide $\left(\mathrm{CH}_{2} \mathrm{CHCONH}_{2}\right)$ is a reactive compound which can readily undergo vinyl-type polymerisation to produce the industrially useful polymer, polyacrylamide. As a polymer the compound is nontoxic, but in the monomeric form acrylamide is a well recognised neurotoxin (Spencer and

Received for publication 4 November 1977 Accepted for publication 18 January 1978
Schaumburg, 1974a). Acrylamide penetrates intact skin and the effects of sub-clinical exposures are cumulative (Spencer and Schaumburg, 1974a, 1974b).

Preliminary investigations in this laboratory indicated that acrylamide inhibited PMN chemotaxis in vitro, thus suggesting that acrylamideintoxicated individuals may be more susceptible to bacterial infections. To follow up these findings, and because of an increased interest in the biological effects of important industrial chemicals, the effect of acrylamide on human PMN functions in vitro was investigated.

\section{Materials and methods}

ISOLATION OF PMN LEUCOCYTES

Human PMNs from peripheral venous blood were collected in $10 \mathrm{ml}$ heparinised (143 U/tube) Vacutainer tubes (Becton-Dickinson and Co., Rutherford, NJ). The blood was transferred to vertical sterile siliconised screw-cap tubes $(10 \times 150 \mathrm{~mm})$ and mixed with $5 \mathrm{ml}$ cold heparinised $(10 \mathrm{U} / \mathrm{ml}) 3 \%$ dextran (T500, Pharmacia Fine, Piscataway, NJ) solution in $0.15 \mathrm{M} \mathrm{NaCl}$ and allowed to separate for $30 \mathrm{~min}$ at $37^{\circ} \mathrm{C}$. The leucocyte-rich upper layer was carefully removed with a capillary pipette and centrifuged at $250 \mathrm{~g}$ for $10 \mathrm{~min}$ at room temperature (RT) 
in siliconised glass centrifuge tubes. Residual erythrocytes were lysed by resuspension of the leucocyte pellet in $2 \mathrm{ml}$ of $0.2 \% \mathrm{NaCl}$ for $30 \mathrm{~s}$ followed by the addition of $2 \mathrm{ml}$ of $1.6 \% \mathrm{NaCl}$ (Clark and Kimball, 1971). The leucocytes were repeatedly washed in either cold saline or Hanks balanced salt solution without sodium carbonate (HBSS) and then resuspended in cold saline or HBSS. In the chemiluminescence studies, HBSS without phenol red (HBSS-x) was used. Leucocyte counts were determined with a haemacytometer, or electronically counted (Coulter Electronic Inc., Hialeah, Florida) and adjusted to the required cell concentration with HBSS.

\section{ACR YLAMIDE}

Acrylamide was electrophoresis purity reagent grade and reported to be nearly $100 \%$ pure. Its major contaminant was water, and there were no known contaminating heavy metals or toxic compounds (Bio-Rad, Richmond, California, personal communication).

PRETREATMENT OF PMNS WITH ACRYLAMIDE

Aliquots of the PMN suspension $\left(5 \times 10^{6}\right.$ to $1 \times 10^{7}$ $\mathrm{PMN} / \mathrm{ml}$ ) were added to siliconised $10 \mathrm{ml}$ centrifuge tubes containing equal volumes of various concentrations of acrylamide dissolved in HBSS. Leucocytes mixed with an equal volume of HBSS served as controls. The tubes were gently inverted and incubated in a $35^{\circ} \mathrm{C}$ water bath. After $30 \mathrm{~min}$ the tubes were spun at $250 \mathrm{~g}$ for $5 \mathrm{~min}$ at RT. The cell pellets were washed twice in cold saline and resuspended in HBSS with $10 \%$ pooled human serum to the original volume.

TRYPAN BLUE EXCLUSION

PMNs were examined for viability as determined by ability to exclude trypan blue. A $0.5 \mathrm{ml}$ aliquot of the treated cell suspension was placed in a $12 \times 75 \mathrm{~mm}$ tube. To this, $0.1 \mathrm{ml}$ of a $0.4 \%$ solution of trypan blue in saline (Gibco, Grand Island, NY) was added, the cell suspension was mixed thoroughly and allowed to stand for $10 \mathrm{~min}$ at RT. The number of stained (damaged) and unstained (undamaged) leucocytes were counted and the results expressed as percentage viable cells.

PRODUCTION OF THE POSITIVE

CHEMOTACTIC STIMULUS (PCS)

The chemotactic fragment of complement, C5a, was generated as described by Ward (1976). Zymosan $(10 \mathrm{mg})$ was added to fresh serum $(1 \mathrm{ml})$ and incubated at $37^{\circ} \mathrm{C}$ for $1 \mathrm{~h}$. This preparation was diluted $1: 10$ in HBSS for use in the chemotaxis assay.
CHEMOTAXIS ASSAY

A modified Boyden chamber (Belco Glass Co., Vineland, NJ) was used to assess PMN migration (Boyden, 1962). The chamber consists of an upper and lower compartment separated by a cellulose membrane with a pore size of $5 \mu \mathrm{m}$ and a thickness of about $125 \mu \mathrm{m}$. One ml of the PMN suspension adjusted to $2.5 \times 10^{6}$ cells $/ \mathrm{ml}$ was added to the upper compartment and $0.5 \mathrm{ml}$ of the PCS was loaded into the lower compartment. The chambers were incubated at $37^{\circ} \mathrm{C}$ for $3 \mathrm{~h}$ after which the filters were washed, stained with haematoxylin, cleared in xylene, inverted, and mounted on glass slides (Ward, 1976). Migration was determined by scoring all cells (PMNs) which had migrated into the filter $50 \mu \mathrm{m}$ or more from the starting side. Seven to ten random high power $(\times 210)$ fields were averaged per filter. Triplicate chambers were used for each concentration of acrylamide tested.

\section{BACTERIA}

The Staphylococcus epidermidis strain was obtained from a departmental stock culture held at $4^{\circ} \mathrm{C}$ on a nutrient agar slant. The culture was checked for purity by subculture on to blood agar, Gram staining and biochemical testing.

\section{PMN INGESTION AND BACTERICIDAL}

\section{CA PACITY}

Staphylococcus epidermidis was grown for $18 \mathrm{~h}$ in 8 $\mathrm{ml}$ of Tryptic soy broth (Difco) at $35^{\circ} \mathrm{C}$. The cultures were centrifuged, the bacterial pellet washed twice with cold saline, and resuspended to the original volume in cold saline. A 1:10 dilution of this suspension, normally yielding around $10^{6}$ colonyforming units (CFU) per $\mathrm{ml}$, served as the working concentration.

Ingestion and bactericidal capacity of the acrylamide-treated PMNs were determined by a modification of the methods described by Mandell and Hook (1969). Two ml of the PMN cell suspensions were transferred to sterile siliconised $13 \times 100$ $\mathrm{mm}$ screw-cap tubes. To each tube $0.1 \mathrm{ml}$ of the staphylococcal suspension was added. This provided a bacteria: PMN ratio of approximately $1: 100$. Each tube was gently inverted and a $0.6 \mathrm{ml}$ aliquot was immediately removed and placed in chilled sterile centrifuge tubes. This was the ' 0 time' specimen. The leucocyte-bacteria suspensions were incubated at $37^{\circ} \mathrm{C}$ with end-over-end rotations (Roto-rack, Fisher Scientific Co., Pittsburgh, Pa.). At 30, 60, and $120 \mathrm{~min}, 0.6 \mathrm{ml}$ aliquots were removed from each tube.

From each $0.6 \mathrm{ml}$ aliquot taken at each time interval, $0.1 \mathrm{ml}$ was added to a $9.9 \mathrm{ml}$ sterile distilled water blank and vigo ${ }^{\prime}$ ously shaken to disrupt the 
PMNs. Viable bacteria were counted by standard dilution and pour plate methods. These counts represented the total number of live bacteria, both intracellularly and extracellularly, in the leucocytebacteria suspension. To the remaining $0.5 \mathrm{ml}$ of the sample aliquot, $4.5 \mathrm{ml}$ cold sterile saline was added and mixed gently. The tubes were centrifuged at 250 $g$ for $5 \mathrm{~min}$, after which the supernate was assayed for viable bacteria. This count represented bacteria which were not ingested and not killed by the extracellular release of leucocyte lysosomal enzymes. The PMN pellet (approximately $0 \cdot 1 \mathrm{ml}$ ) was resuspended in $4.5 \mathrm{ml}$ sterile water, vigorously shaken, and the viable bacteria counted. This count represented bacteria which had been engulfed, but not killed, and bacteria which had been trapped by PMN aggregations during centrifugation.

\section{CHEMILUMINESCENCE}

Human PMNs were isolated, as previously described, and resuspended to a concentration of $5 \times 106 / \mathrm{ml}$ in HBSS-x. The cells were treated with acrylamide, washed twice in HBSS-x, and resuspended in HBSS- $x$ with $10 \%$ fresh autologous serum (i.e. serum from the same volunteer from which PMNs had been obtained).

Staphylococcus epidermidis was grown for 18-20 h in $8 \mathrm{ml}$ Tryptic soy broth at $35^{\circ} \mathrm{C}$. The cultures were centrifuged, washed twice in cold saline and the pellet was then opsonised with $3 \mathrm{ml}$ of fresh autologous serum for $30 \mathrm{~min}$ at $35^{\circ} \mathrm{C}$. The cells were then spun at $250 \mathrm{~g}$ at room temperature for $5 \mathrm{~min}$, washed once in HBSS-x, and resuspended in this same buffer to original volume. This yielded about $10^{7}$ viable bacteria per $\mathrm{ml}$.

Chemiluminescence (CL) was measured in a Packard scintillation spectrometer, Model 3320, operating at $4^{\circ} \mathrm{C}$ using the out-of-coincidence summation mode, with a window setting at $0-\infty$ and $100 \%$ gain (Allen et al., 1972, 1974). All procedures were performed under dim light to minimise background light emission. Siliconised glass scintillation vials were dark-adapted for at least $24 \mathrm{~h}$ before use. One $\mathrm{ml}$ of leucocytes was added to duplicate vials and warmed for $5 \mathrm{~min}$ in a $35^{\circ} \mathrm{C}$ water bath. The background CL of each vial was measured for $20 \mathrm{~s}$ at $5 \mathrm{~min}$ intervals over a total period of $15 \mathrm{~min}$. At the end of this time, $1 \mathrm{ml}$ of HBSS-x was added to one of the duplicate vials ('resting cells') and $1 \mathrm{ml}$ of opsonised bacterial suspension was added to the other vial ('activated cells'). The addition of the HBSS-x or bacteria was staggered so that measurement of $C L$ was at equal times from time 0 . To measure $C L$, each vial was removed from the water bath, blotted dry, the HBSS-x or bacteria added, gently mixed, and immediately lowered into the scintillation counter (about 20-30 s after the addition). CL was measured for a $20 \mathrm{~s}$ interval and the vial was returned to the water bath. Corrected counts for each vial were obtained by subtracting the average background CL during the initial $15 \mathrm{~min}$ period from the CL obtained after aciivation of the cells with either HBSS-x or bacteria. CL measurement was continued at $5 \mathrm{~min}$ intervals over a period of $45 \mathrm{~min}$.

\section{Results}

TRYPAN BLUE EXCLUSION

Human PMNs exposed to acrylamide were tested for viability by trypan blue exclusion. Pretreatment for $3 \mathrm{~h}$ at $37^{\circ} \mathrm{C}$ with acrylamide in concentrations as high as $37.5 \mathrm{mg} / \mathrm{ml}$ did not lead to staining of the PMNs. Under the light microscope the PMNs treated with acrylamide appeared to have normal morphology.

\section{CHEMOTAXIS}

The Table shows the chemotactic activity of acrylamide-treated and HBSS-pretreated (control) PMNs obtained during a single experiment. Acrylamide in a concentration of $0.5 \mathrm{mg} / \mathrm{ml} \mathrm{had} \mathrm{very} \mathrm{little} \mathrm{effect} \mathrm{on}$ the number of cells migrating toward the PCS, compared with the control cells. Acrylamide concentrations of 1.0 and $5.0 \mathrm{mg} / \mathrm{ml}$ decreased the number of migrating cells by about one-third. Pretreatment with acrylamide at a concentration of $10 \mathrm{mg} / \mathrm{ml}$ inhibited movement of $90 \%$ of the PMNs. It should be noted that changing the concentration of acrylamide five-fold (from $1 \mathrm{mg} / \mathrm{ml}$ to $5 \mathrm{mg} / \mathrm{ml}$ ) did not increase inhibition of chemotaxis above that caused by $1 \mathrm{mg} / \mathrm{ml}$. However, a two-fold increase (from 5 $\mathrm{mg} / \mathrm{ml}$ to $10 \mathrm{mg} / \mathrm{ml}$ ) inhibited chemotaxis by $90 \%$. Whether this suggests that there are two active components in the acrylamide preparation, or that more than one function of chemotaxis is affected, is not known.

\section{PMN INGESTION AND BACTERICIDAL CAPACITY}

To further define the effect of acrylamide on phagocytic functions, bacterial ingestion and killing capacity of pretreated PMNs were studied Ingestion of staphylococci was decreased in PMNs pretreated with $10.0 \mathrm{mg} / \mathrm{ml}$ acrylamide, the concentration at which chemotaxis was severely inhibited (Fig. 1). Similar data were obtained from two separate experiments. Stained smears of the leucocytes removed at various times from the reaction mixture showed intracellular bacteria in both acrylamideand control-pretreated PMNs. 
Table PMN chemotaxis after pretreatment with acrylamide

\begin{tabular}{lll}
\hline $\begin{array}{l}\text { Acrylamide } \\
\text { concentration } \\
(\mathrm{mg} / \mathrm{ml})^{*}\end{array}$ & $\begin{array}{l}\text { Chemotactic } \\
\text { activity } \\
(\text { cells/HPF†) }\end{array}$ & $\%$ inhibition \\
\hline Control & $236.9 \pm 12.6$ & - \\
0.5 & $235.7 \pm 40.1$ & 0.5 \\
1.0 & $156.6 \pm 26.2$ & 33.9 \\
5.0 & $168.9 \pm 20.3$ & 28.7 \\
10.0 & $23.2 \pm 5.6$ & 90.2 \\
\hline
\end{tabular}

Positive chemotactant: zymosan-treated fresh human serum. * Final concentration of acrylamide in the pretreatment reaction mixture.

$\dagger$ Numbers represent the mean number of cells per high power field ( $\times 210) \pm$ standard error of the mean, which have migrated at least $50 \mu \mathrm{m}$ into the filter. Results from three chambers.

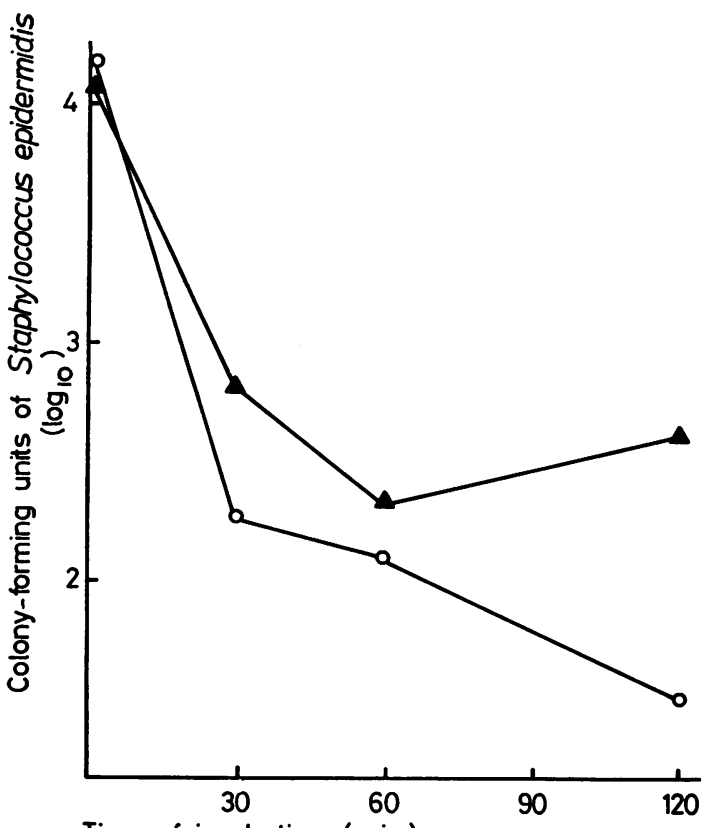

Time of incubation ( $\mathrm{min}$ )

Fig. 1 Ingestion of bacteria by PMNs pretreated with acrylamide. The ordinate represents the number of Staphylococcus epidermidis escaping ingestion after incubation with $P M N$ s pretreated with acrylamide $(10 \cdot 0$ $\mathrm{mg} / \mathrm{ml}$ ) (A) or $\mathrm{HBSS}$ (control) (O) for 30 min at $35^{\circ} \mathrm{C}$. These values were obtained by counting the bacteria in the supernatant remaining after removal of the PMNs by centrifugation.

A diminished intracellular killing capacity was detected by the inability of acrylamide-pretreated PMNs to destroy ingested bacteria. Figure 2 depicts data from one of two experiments which yielded similar results. The control PMNs reduced the number of cell-associated bacteria from $4 \times 10^{4}$ to

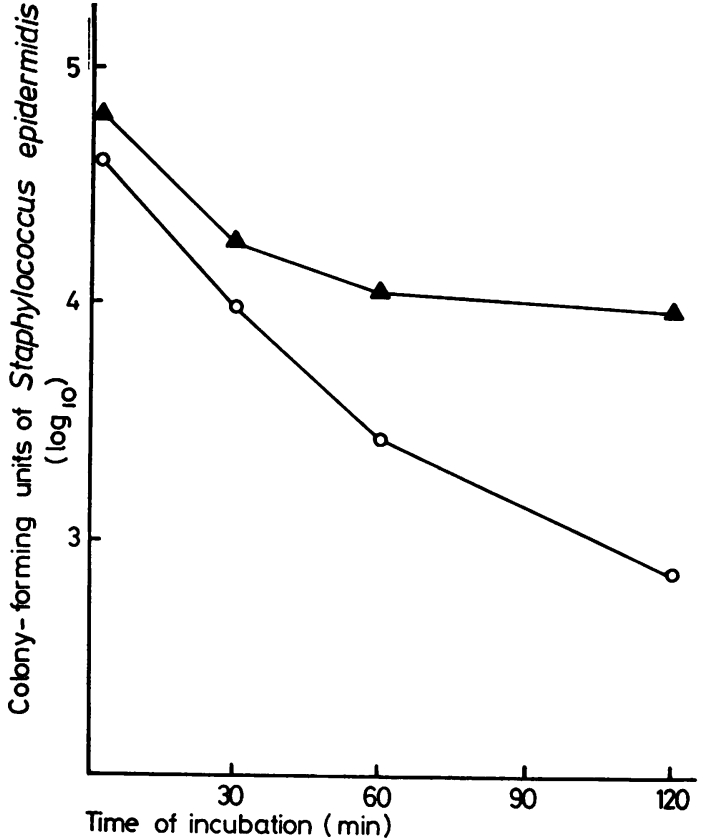

Fig. 2 Intracellular bactericidal activity of PMNs pretreated with acrylamide. The ordinate represents the number of Staphylococcus epidermidis ingested but not killed by PMNs pretreated with acrylamide $(10 \cdot 0$ $\mathrm{mg} / \mathrm{ml}$ ) (A) or HBSS (control) (O) for 30 min at $35^{\circ} \mathrm{C}$. These values were obtained by sedimenting the PMNs by centrifugation. The bacteria were released from the PMNs by lysis and counted.

$7 \times 10^{2} \mathrm{CFU} / \mathrm{ml}$ over the $120 \mathrm{~min}$ period. In comparison, the number of viable intracellular bacteria in the acrylamide-pretreated sample decreased from $7 \times 10^{4}$ to $9 \times 10^{3} \mathrm{CFU} / \mathrm{ml}$ over the same period.

The total bactericidal capacity (intracellular and extracellular) of PMNs pretreated with acrylamide is shown in Fig. 3. Concentrations of acrylamide above $5.0 \mathrm{mg} / \mathrm{ml}$ depressed total bactericidal capacities compared with the control, while concentrations below $5.0 \mathrm{mg} / \mathrm{ml}$ increased bacterial killing. PMNs pretreated with $5.0 \mathrm{mg} / \mathrm{ml}$ acrylamide had a killing capacity similar to the control PMNs. The small increase in the number of bacteria in samples lacking PMNs did not appear substantially to affect the results of the test.

\section{CHEMILUMINESCENCE}

CL was used as a measure of PMN oxidative metabolism during phagocytosis (Allen et al., 1972, 1974). Control PMNs, activated with opsonised Staphylococcus epidermidis, gave reproducible results with maximal CL of about 7000- 


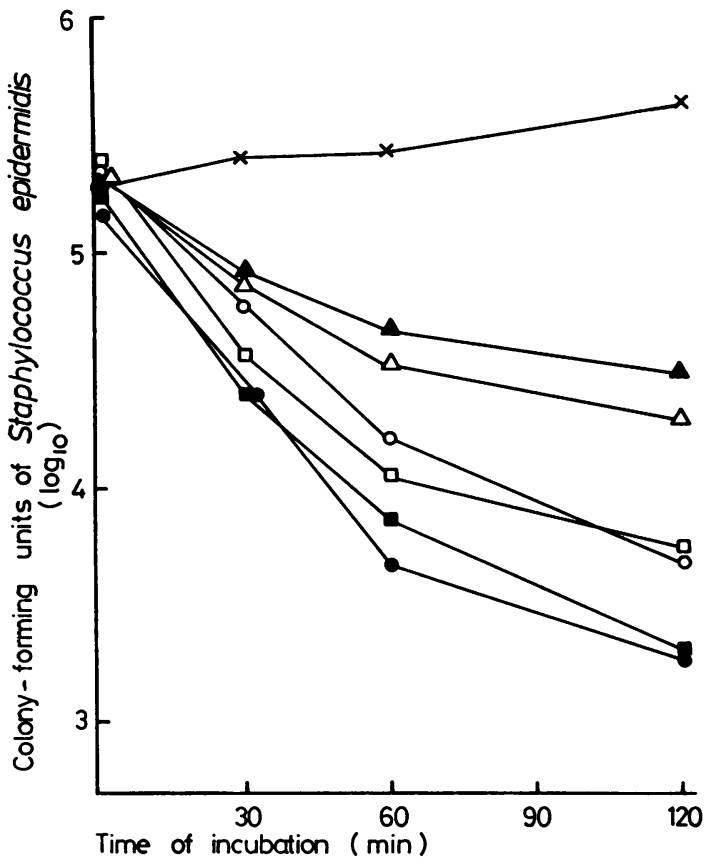

Fig. 3 Total bactericidal capacity of PMNs pretreated with varying concentrations of acrylamide. The ordinate represents the total viable Staphylococcus epidermidis remaining after incubation with $P M N$ s pretreated with acrylamide in concentrations of $1.0(0), 2.5(\square), 5.0$ ( $\square$ ), $7.5(\triangle)$, and $10.0(\Delta) \mathrm{mg} / \mathrm{ml}$ or $\mathrm{HBSS}$ (control) (O) for 30 min at $35^{\circ} \mathrm{C}$. The number of viable bacteria in tubes lacking PMNs (bacteria control) was also measured $(x)$. These counts were obtained by diluting the PMN-bacterial suspension in distilled water. The counts represent surviving intra- and extra-cellular bacteria.

11000 counts $/ 20$ s. CL peaked at approximately 10 $15 \mathrm{~min}$ and then gradually decreased over the remainder of the $45 \mathrm{~min}$ period. Acrylamide pretreatment led to dose-dependent inhibition of CL (Fig. 4). PMNs pre-incubated with acrylamide at a concentration of $10.0 \mathrm{mg} / \mathrm{ml}$ had peak $\mathrm{CL}$ values about half those of control PMNs, whereas PMNs pre-incubated with acrylamide at concentrations of 1.0 and $0.1 \mathrm{mg} / \mathrm{ml}$ had peak $C L$ values approximately $80 \%$ of that of the controls. Acrylamide-pretreated PMNs showed a more rapid decrease in CL during the last $25 \mathrm{~min}$ of the $45 \mathrm{~min}$ period compared with the controls.

\section{Discussion}

The results presented in this report indicate that acrylamide in high concentrations has an inhibitory

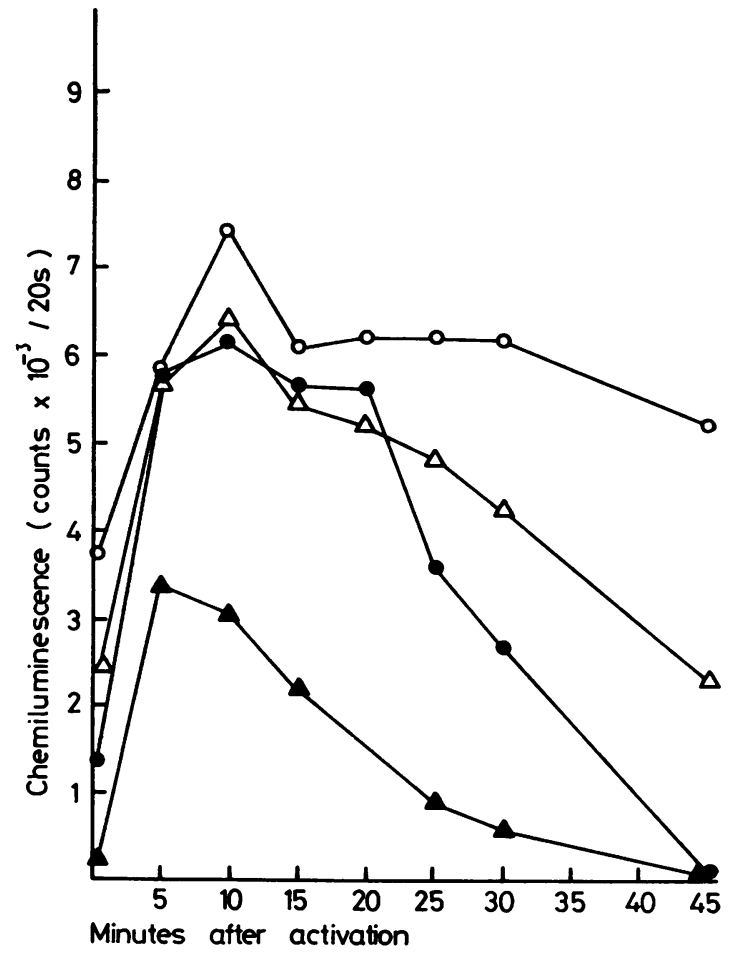

Fig. 4 Chemiluminescence from activated PMNs pretreated with various concentrations of acrylamide. The ordinate represents the chemiluminescence emitted from $P M N$ s pretreated with acrylamide in concentrations of $0 \cdot 1(\triangle), 1 \cdot 0(\mathrm{O})$, and $10.0(\Delta) \mathrm{mg} / \mathrm{ml}$ or $\mathrm{HBSS}$ (control) (O) for 30 min at $35^{\circ} \mathrm{C}$. PMNs were activated by addition of opsonised Staphylococcus epidermidis.

effect on several human PMN phagocytic functions in vitro. The action of acrylamide does not appear to be directed at any particular aspect of the cell biology, such as movement, respiration or phagocytosis. Whether acrylamide blocks each function individually or inactivates mechanisms common to several or all the functions is not known.

High concentrations $(37.5 \mathrm{mg} / \mathrm{ml})$ of acrylamide did not affect viability measured by lack of trypan blue uptake. However, chan es in staining properties are insensitive indicators of cell damage and phagocytic integiity, compared with measurements of respiration and bactericidal capacity (Dankberg and Persidsky, 1976).

Acrylamide is known to react with proteins (Druckerey et al., 1953; Hashimoto and Aldridge, 1970). Inhibition of phagocytic functions could result from acrylamide binding to, and inactivating, several key enzymes involved in important neutrophil biochemical reactions, such as glycolysis, 
oxygen metabolism, and membrane transport of cations (Karnovsky, 1962; Naccache et al., 1977). Ward and Becker $(1967,1968,1970)$ and Becker and Ward (1967) have shown that recognition of neutrophil chemotactic factors may be dependent upon serine esterases on the cell surface. Inactivation of these proteins by acrylamide could therefore block their role in phagocytic recognition.

Colchicine, which blocks microtubule formation, inhibits several PMN functions including chemotaxis, adhesiveness, random motility, degranulation, ingestion, and metabolic stimulation (Bodel and Malawista, 1967; Caner, 1965). In a similar manner, disruption of the polymerisation of tubulin subunits or an alteration of the microtubular functions by acrylamide binding to these proteins could inhibit phagocytic activity.

Druckerey et al. (1953) showed that mixtures of acrylamide and protein brines or human serum solidify into a clear gel. Pretreatment of PMNs with acrylamide may cause conjugation of proteins on the cell membrane or within the cytosol, thereby decreasing the fluidity of the cell. Alternatively, acrylamide bound to the surface of the phagocyte might cause the serum in the reaction mixture to solidify as a gel around each cell. Decreases in cell flexibility could explain the diminished random motility, chemotaxis, and bacteria (particle) uptake, and would also affect degranulation and metabolic stimulation, which are dependent on membrane perturbation (Goldstein et al., 1976, 1977).

Acrylamide is known to polymerise on the surface of tumour cells because of the presence of free radicals (Burlakova et al., 1966). Production of free radicals by the PMNs during incubation with acrylamide (Allen et al., 1972, 1974) may polymerise acrylamide on the PMN surface, leading to decreased cell flexibility and masking of surface receptors.

PMN chemiluminescence, a measure of cellular oxidative metabolism, arises from the production and subsequent relaxation of high-energy compounds associated with oxygen consumption during phagocytosis (Allen et al., 1972, 1974; Cheson et al., 1976). As CL correlates with bactericidal activity in the PMN (Allen et al., 1972), the decrease in killing capacity by acrylamide-pretreated PMNs may be attributable to inactivation of the bactericidal mechanisms measured by CL.

The stimulation of the bactericidal capacities of these cells with concentrations of acrylamide below $5.0 \mathrm{mg} / \mathrm{ml}$ was unexpected because acrylamide in the same concentrations slightly depressed chemotaxis and chemiluminescence. As both movement and oxidative metabolism appear to be inhibited, low concentrations of acrylamide may enhance other steps of phagocytosis such as opsonisation (recognition), ingestion, degranulation, or non-oxidative bactericidal systems. The mechanism for this enhancement remains to be investigated.

Irrespective of the in vitro effects, it is unlikely that the accumulation of acrylamide would affect PMN function in vivo. First, the dose of acrylamide necessary to inhibit PMN function in vitro (10 $\mathrm{mg} / \mathrm{ml}$ ) appears to be high. It should be stressed that the amount of acrylamide which interacts with each PMN is unknown, as the cells were washed before being tested. The concentration of acrylamide that inh bits PMN function in experimental animals has not been determined. Second, acrylamide does not attach selectively to PMNs in vivo. Hashimoto and Aldridge (1970) found that, after acute intoxication of test animals, radiolabelled acrylamide was bound to protein in many tissues. Whether bound acrylamide is not available or is non-toxic for PMNs is uncertain, but it seems likely that only those PMNs in the vicinity of penetration (and highest concentration) of acrylamide would be affected. Third, PMNs have a half-life of $6 \mathrm{~h}$ in the blood, and survive in the body tissues for less than two days (Leeson and Leeson, 1970). Thus, the time during which acrylamide can accumulate in a single PMN is limited by the cell's short life span. However, this does not rule out the possibility of inhibitory effects resulting from a single massive exposure to acrylamide.

The data reported here suggest that additional studies are necessary to determine the effect of acrylamide on host susceptibility to infectious agents and on those systems which determine such susceptibility. Because acrylamide is used in industrial processes, its effects must be clearly evaluated. Further studies on the mechanism by which acrylamide inhibits phagocytosis are also warranted.

This investigation was supported in part by a grant from the West Virginia University School of Medicine (BRSG and Medical Corporation Funds). We thank Dr Robert Burrell for his advice in the preparation of the manuscript. The secretarial assistance of Mrs Elizabeth Rocovich, Mrs Teresa Grimm, and Mrs Lillian Scanga is gratefully acknowledged.

\section{References}

Allen, R. C., Stjernholm, R. L., and Steele, R. H. (1972). Evidence for the generation of an electronic excitation state(s) in human polymorphonuclear leukocytes and its participation in bactericidal activity. Biochemical and Biophysical Research Communications, 47, 679-684. 
Allen, R. C., Yevich, S. J., Orth, R. W., and Steele, R. H. (1974). The superoxide anion and singlet molecular oxygen: their role in the microbicidal activity of the polymorphonuclear leukocyte. Biochemical and Biophysical Research Communications, 60, 909-917.

Becker, E. L., and Ward, P. A. (1967). Partial biochemical characterization of the activated esterase required in the complement dependent chemotaxis of rabbit leukocytes. Journal of Experimental Medicine, 125, 1021-1030.

Beisel, W. R., and Rapoport, M. I. (1969). Adrenal cortical functions and infectious illness. New England Journal of Medicine, 280, 596-604.

Bodel, P., and Malawista, S. (1967). The dissociation by colchicine of phagocytosis from increased oxygen consumption in human leukocytes. Journal of Clinical Investigation, 46, 786-796.

Boyden, S. (1962). The chemotactic effect of mixtures of antibody and antigen on polymorphonuclear leukocytes. Journal of Experimental Medicine, 115, 453-466.

Brayton, R. G., Stokes, P., Schwartz, M. S., and Louris, D. D. (1970). Effect of alcohol and various diseases on leukocyte mobilization, phagocytosis, and intracellular bacterial killing. New England Journal of Medicine, 282 123-128.

Burlakova, E. V., Ismailova, S. K., and Kozlov, Y. P. (1966). Inhibition of the growth of plant tissue tumour cells by radical polymerisation of substances. Trudy Moskovskogo obshchestva ispytatelei prirody, Otdel biologicheskii, 16, 207-210. (Cited in Chemical Abstracts, 66, 53010, 1967). (In Russian with English abstract).

Caner, J. E. Z. (1965). Colchicine inhibition of chemotaxis. Arthritis and Rheumatism, 8, 757-764.

Cheson, B. D., Christensen, R. L., Sperling, R., Kohler, B. E., and Babior, B. M. (1976). The origin of the chemiluminescence of phagocytosing granulocytes. Journal of Clinical Investigation, 58, 789-796.

Clark, R. A., and Kimball, H. R.(1971). Defective granulocyte chemotaxis in the Chediak-Higashi syndrome. Journal of Clinical Investigation, 50, 2645-2652.

Dankberg, F., and Persidsky, M. D. (1976). A test of granulocyte membrane integrity and phagocytic function. Cryobiology, 13, 430-432.

Druckerey, H., Consbruch, U., and Schmahl, D. (1953). Effects of monomeric acrylamide on proteins. Zeitschrift für Naturforschung, 86, 145-150.

Goldstein, I. M., Cerqueira, M., Lind, S., and Kaplan, H. B (1977). Evidence that the superoxide-generating system of human leukocytes is associated with the cell surface. Journal of Clinical Investigation, 59, 249-254.

Goldstein, I. M., Kaplan, H. B., Rakin, A., and Frosh, M. (1976). Independent effects of IgG and complement upon human polymorphonuclear leucocyte function. Journal of Immunology, 117, 1282-1287.

Hashimoto, K., and Aldridge, W. N. (1970). Biochemical studies on acrylamide: a neurotoxic agent. Biochemical Pharmacologv, 19, 2591-2604.

Holmes, B., Page, A. R., and Good, R. A. (1967). Studies of the metabolic activity of leukocytes from patients with a genetic abnormality of phagocytic function. Journal of Clinical Investigation, 46, 1422-1432.

Karnovsky, M. L. (1962). Metabolic basis of phagocytic activity. Physiological Reviews, 42, 143-168.

Leeson, T. S., and Leeson, C. R. (1970). Specialized connective tissue: Blood. In Histology, pp. 134-154. W. B. Saunders Co.: Philadelphia, Pa.

Mandell, G. L., and Hook, E. W. (1969). Leukocyte function in chronic granulomatous disease of childhood. American Journal of Medicine, 47, 473-486.

Miller, M. E., Oski, F. A., and Harris, M. B. (1971). Lazyleucocyte syndrome: a new disorder of neutrophil function. Lancet, 1, 665-669.

Naccache, P. H., Showell, H. J., Becker, E. L., and Sha'afi, R. I. (1977). Transport of sodium, potassium, and calcium across rabbit polymorphonuclear leukocyte membranes. Journal of Cell Biology, 73, 428-444.

Quie, P. G., White, J. G., Holmes, B., and Good, R. A. (1967). In vitro bactericidal capacity of human polymorphonuclear leukocytes: diminished activity in chronic granulomatous disease of childhood. Journal of Clinical Investigation, 46, 668-679.

Spencer, P. S., and Schaumburg, H. H. (1974a). A review of acrylamide neurotoxicity. Part I. Properties, uses, and human exposure. Canadian Journal of Neurological Sciences, 1, 143-150.

Spencer, P. S., and Schaumburg, H. H. (1974b). A review of acrylamide neurotoxicity. Part II. Experimental animal neurotoxicity and pathogenic mechanisms. Canadian Journal of Neurological Sciences, 1, 152-169.

Ward, P. A. (1976). Chemotaxis. In Manual of Clinical Immunology, pp. 106-109. Edited by N. R. Rose and H. Friedman. American Society for Microbiology: Washington, D.C.

Ward, P. A., and Becker, E. L. (1967). Mechanisms of the inhibition of chemotaxis by phosphonate esters. Journal of Experimental Medicine, 125, 1001-1020.

Ward, P. A., and Becker, E. L. (1968). The deactivation of rabbit neutrophils by chemotactic factor and the nature of the activatable esterase. Journal of Experimental Medicine, 127, 693-709.

Ward, P. A., and Becker, E. L. (1970). Biochemical demonstration of the activatable esterase of the rabbit neutrophil involved in the chemotactic response. Journal of Immunology, 105, 1057-1067. 